STUDIA PRAWNO-EKONOMICZNE, T. CXVII, 2020

PL ISSN 0081-6841; e-ISSN 2450-8179 $\quad$ s. 129-141

https://doi.org/10.26485/SPE/2020/117/8

Beata ROGOWSKA-RAJDA*

iD https://orcid.org/0000-0003-3879-3440

Tomasz TRATKIEWICZ**

iD https://orcid.org/0000-0001-7772-1779

\title{
DEDUCTION AND ADJUSTMENT OF INPUT VAT AS REGARDS ECONOMIC AND NON-ECONOMIC USE OF GOODS AND SERVICES
}

\begin{abstract}
Background: The aim of the study was to analyse EU legislation and case-law on the deduction and adjustment of input VAT regarding economic and non-economic use of goods and services. This issue has been the focus of much controversy in recent years and has been the subject of several rulings by the Court of Justice of the European Union, the VAT Committee discussions, as well as the rulings of administrative courts and the interpretations of the Minister of Finance/ Director of National Revenue Information in Poland. The study conducted a comprehensive legal analysis of the issue, at the same time drawing attention to the doubts that still exist despite the CJEU judgments.

Research purpose: The aim of the study was not only to assess the relevant legislation or its interpretation, but above all to draw attention to the need to fill the legislative gap in the area studied, which has led, and may continue to lead, to non-uniform application of VAT rules in the EU Member States.

Methods: The study was carried out predominantly using the empirical-dogmatic method, backed by a historical method and comparative method.

Conclusions: Significant differences between the Member States of the European Union in terms of the deduction and the adjustment of input VAT regarding goods and services used for mixed purpose were identified. Despite the recent CJEU judgments, there is still a relatively large margin for interpretation, which may result in different legal and tax positions of entities in the EU Member States. There is therefore a need to adopt the EU legislation in this area.
\end{abstract}

Keywords: VAT, deduction and adjustment of input VAT, economic and non-economic activity, neutrality principle.

* PhD, University of Warsaw, Faculty of Economic Sciences, Department of Banking, Finance and Accounting; e-mail: brogowska@wne.uw.edu.pl

** PhD, University of Lodz, Faculty of Economics and Sociology, Department of Public Finance; e-mail: tomasz.tratkiewicz@uni.lodz.pl 


\section{Introduction}

Deduction of input VAT in a situation when a taxable person is carrying out economic activities both inside and outside the VAT system seems to be an issue of a marginal significance. After all, the status of a taxable person is inherently connected with performing economic activities, in most cases activities which are profit-oriented. Nothing could be further from the truth. The problem concerns - in a broad perspective - public law bodies which, in current circumstances, operate in a specific role, mostly due to the fact that the European Union regulations are not adjusted to evolving economic realities.

On the one hand, public law bodies - carrying out the primary tasks they were established for - act as public authorities, on the other hand - as economic enterprises, including - among others - the area of culture and education. Consequently, public bodies carry out their tasks according to three different relationship with VAT, depending on each task's specific nature:

: activities which are outside the VAT system (not meeting the criteria set up in the definition of an economic activity or performed as public authorities), activities taxed with VAT, or those that are VAT exempt. Similar specificity may also occur in foundations, associations, or other non-governmental organisations, and - regarding more commercial field - in holdings.

Public law bodies' right to deduct VAT and the scope to which it can be exercised is strictly connected with the above-mentioned issue. Although making VAT deductions in a situation when activities subject to VAT and those that are VAT exempt are carried out simultaneously does not generate particular problems, making deduction when there are some activities carried out outside the VAT system does pose some difficulties. This applies not only to the initial deduction made in the moment of acquiring goods or services but also to the subsequent adjustment of that deduction as well. Initial deduction (determined by acting as a taxable person at the moment of acquisition) is based only on a taxable persons' intention of using the acquired goods or services for carrying out VAT taxable transactions. It is therefore necessary to make its subsequent verification, consistent with the actual usage of the acquired goods, and potential adjustments.

The Article attempts to identify and clarify rules stemming from 2006/112/ EC Directive ${ }^{1}$ and the case-law of the Court of Justice of the European Union

Council Directive 2006/112/EC of 28 November 2006 on the common system of value added tax (OJ L 347, 11.12.2006, p. 1, with subsequent amendments), hereinafter "VAT Directive". 
(hereinafter: CJEU) concerning not only input VAT deduction in a situation of expenditure incurred both for the aim of economic activities as well as for activities outside the VAT system ${ }^{2}$, but also the obligation to make subsequent adjustment of that deduction. The Article also draws attention to the continuing need, despite the recent judgments of the CJEU, to regulate these issues uniformly at the European Union level.

\section{2. "Initial" deduction of input VAT}

According to the construction of the system set out in the Sixth Directive ${ }^{3}$, as subsequently replaced by VAT Directive, input VAT on goods and services used by a taxable person for his taxable activities is deductible. Input VAT deduction relates to output VAT collection. In so far as goods and services are used for taxable activities, output VAT deduction prevents double taxation. However, when goods or services acquired by a taxable person are used for carrying out both VAT exempt activities or transactions that do not fall within the scope of VAT, there is neither output VAT collection nor input VAT deduction ${ }^{4}$.

In order for VAT to be deductible, activities resulting in input VAT (the input transactions) must have a direct and immediate link with activities subject to output VAT (the output transactions) giving rise to a right of deduction. There is a direct link when expenditure incurred represents a component of the cost of the output transactions that give rise to the right to deduct ${ }^{5}$. However, a taxable person also has a right to deduct even where there is no direct and immediate link between a particular input transaction and an output transaction or transactions giving rise to the right to deduct, where the costs of the transactions in question are part of the general costs of a taxable person and are, as such,

2 The article disregards issues relating to the private use of purchased goods, once they have been regulated in Directive 2006/112/EC and national legislation, they no longer do not raise major interpretative doubts.

3 Council Directive 77/388/EEC of 17 May 1977 on the harmonization of the laws of the Member States relating to turnover taxes - Common system of value added tax: uniform basis of assessment (OJ L 145, 13.6.1977, p. 1, with subsequent amendments).

4 CJEU judgements: of 14 September 2006 in case Wollny (C-72/05, paragraph 20); and of 30 March 2006 in case Uudenkaupungin kaupunki (C-184/04, paragraph 24).

5 CJEU judgements: of 27 September 2001 in case Cibo (C-16/00, paragraph 31); of 26 May 2005 in case Kretztechnik (C-465/03, paragraph 36); of 8 February 2007 in case Investrand (C-435/05, paragraph 23); of 6 September 2012 in case Portugal (C-496/11, paragraph 36); of 16 July 2015 in joined cases Larentia (C-108/14 and C-109/14, paragraph 23). 
components of the price of the goods or services which he supplies. Such costs, indeed, have a direct and immediate link with the taxable person's economic activities as a whole ${ }^{6}$. In the light of the foregoing CJEU guidelines, where a taxable person simultaneously carries out economic and non-economic activities outside the scope of VAT Directive, deduction of the input VAT relating to expenditure connected concurrently with both of the above-mentioned types of activities is allowed only to the extent that expenditure can be attributed to the taxable person's economic activity covered by the VAT system ${ }^{7}$.

In case of carrying out the activities outside of the VAT system (i.e. the activities not meeting the criteria of an economic activity or activities performed as a public authority), in addition to the activities subject to VAT, that constitute the core business of a particular taxable person, the principle of immediate deduction, developed by CJEU in its case-law regarding the usage of capital goods for private purposes by a taxable person, does not apply ${ }^{8}$.

The impossibility of applying Article 26 of the Directive is the direct reason for the situation described". The provision mentioned, using the term "purposes other than those of the business", covers - in general - only private purposes. The regulation does not therefore cover non-private usage of capital goods, that are not covered by the scope of VAT, particularly if the realisation of those purposes represents the core activity of a taxable person ${ }^{10}$. Due to this reason, the

6 CJEU judgements in cases: Cibo (C-16/00, paragraph 33); Portugal (C-496/11, paragraph 37); in joined cases, Larentia (C-108/14 and C-109/14, paragraph 24).

7 CJEU judgements: of 13 March 2008 in case Securenta (C-437/06, paragraph 31); of 12 February 2009 in case VNLTO (C-515/07, paragraph 27).

8 CJEU judgements: of 21 April 2005 in case $H E$ (C-25/03, paragraph 46); of 14 July 2005 in case Charles and T.S. Charles-Tijmens (C-434/03, paragraph 23); of 14 September 2006 in case Wollny, C-72/05, paragraph 21; of 23 April 2009 in case Puffer (C-460/07, EU:C:2009:254, paragraph 39); of 16 February 2012 in case Eon Aset Menidjmunt (C-118/11, paragraph 53); of 16 February 2012 in case T.G. van Laarhoven (C-594/10, paragraph 25).

9 For more information see: B. Rogowska-Rajda, T. Tratkiewicz, Nieodpłatne świadczenie ustug w podatku VAT w orzecznictwie Trybunału Sprawiedliwości, Europejski Przegląd Sądowy $2015 / 11$, pp. 38-41.

10 Opinions of Advocate Generals: of 22 December 2008 in case VNLTO (C-515/07, paragraph 55); of 20 January 2005 in case Charles and T.S. Charles-Tijmens (C-434/03, paragraph 59); of 10 April 2014 in case Gemeente's Hertogenbosch (C-92/13, paragraphs 17, 51 and 56); of 6 April 2017 in case Iberdrola (C-132/16, paragraph 51); CJEU judgements of 30 March 2006, in case Uudenkaupungin kaupunki (C-184/04, paragraph 33); of 10 September 2014 in case Gemeente's Hertogenbosch (C-92/13, paragraphs 25-26); see also: B. Rogowska-Rajda, T. Tratkiewicz, Odliczanie podatku naliczonego VAT od wydatków zwiazanych z samochodami w świetle prawa unijnego, Europejski Przegląd Sądowy 2017/4, p. 16. 
principles governing the possibility to allocate capital goods to business and private assets could not be transposed to a situation in which a taxable person carries out both taxable economic activities and non-economic activities, falling outside the scope of VAT, however constituting the main corporate purpose of the taxable person ${ }^{11}$.

The provisions of VAT Directive do not formulate principles regarding methods and criteria - the Member States are obliged to apply when adopting regulations allowing the apportionment of input VAT - according to which the allocation of expenditure incurred to economic activities or to non-economic activities could be done. In order for taxable persons to make necessary deductions, it is for the Member States to determine methods and criteria appropriate for that purpose and consistent with the principles underlying the common system of VAT. The Member States should make use of their discretion in such a way that ensures the deduction is solely made for that part of VAT proportional to the amount attributed to the transactions giving rise to the right to deduct. They should make efforts so that the calculation of the proportion between economic activities and non-economic activities could objectively reflect the part of the input expenditure actually attributed, respectively, to those two types of activity. When exercising that discretion, the Member States have the right to apply, in a specific case, an investment formula or a transaction formula or any other appropriate formula, without being required to restrict themselves to only one of those methods ${ }^{12}$. In the opinion of the Authors, European Union law does not require determining methods and criteria of input VAT apportionment between economic and non-economic activities directly in the national legislation. From the CJEU perspective, this is not the form of fulfilling the Member States' responsibilities that is essential but the compliance of the adopted solutions with the neutrality principle. Therefore, it is also permitted to determine the above-mentioned methods and criteria of input VAT apportionment on the basis of the practice accepted by the national tax authorities, with due regard to the principle of neutrality ${ }^{13}$. Moreover, in the view of the Authors, while deter-

11 Opinion of Advocate General in case Gemeente's Hertogenbosch (C-92/13, paragraphs 17, 51 and 56). The theses of the Opinion were confirmed by CJEU in its judgement in that case, paragraph 25.

12 CJEU judgements in case Securenta, (C-437/06, paragraphs 33-38); in case Portugal (C-496/11, paragraph 42); in joined cases Larentia (C-108/14 and C-109/14, paragraph 27).

13 Similarly: M. Maliński, Prewspótczynnik VAT - kontrowersje wokót proporcjonalnego odliczenia VAT naliczonego $w$ stanie prawnym przed 1.01.2016 r., Przegląd Podatkowy 2016/11, pp. 22-27; CJEU judgement in joined cases Larentia (C-10814 and C-109/14, para- 
mining and applying said methods and criteria of apportionment, the guidelines developed by the CJEU on proportional VAT deduction regarding taxable and exempt activities can be respectively used. In case of such a mixed use, the Member States have been authorised to determine the proportional part separate for each area of activities or to deduct VAT pursuant to the use of all or part of the goods and services for a particular activity, or to exclude the right to deduct under certain circumstances. The Member States' power is, however, of optional character, constituting an exception to the general principle of proportional deduction, which is based on a turnover, and as such is limited - it can be executed on condition that a given method guarantees a more precise, not necessarily the most precise as possible, determination of the deductible proportion of the input VAT arising from the application of the turnover-based method. The Member States should thus ensure - within the powers conferred upon them - that the calculation of the deductible proportion of the input VAT is as accurate as possible ${ }^{14}$.

This is handled in very different ways across the Member States. It seems that the solutions based on giving the taxable persons flexibility to choose the method prevail provided that the method chosen ensures that the part of expenditure accrued to the economic activities is reflected objectively ${ }^{15}$. According to

graph 31); opinion of Advocate General of 26 March 2015 in joined cases Larentia (C-108/14 and C-109/14, paragraphs 21-23).

14 CJEU judgements in cases: Portugal (C-496/11, paragraph 40); of 8 November 2012, BLC Baumarkt (C-511/10, paragraphs 16 and 23-24); Banco Mais (C-183/13, paragraphs 18 and 29); Wolfgang (C-332/14, paragraphs 32-33); opinion of Advocate General of 25 November 2015 in case Wolfgang (C-332/14, paragraphs 48-50).

15 For example, Poland implemented the rules developed by CJEU in this field - among others - within Article 86.1 and Article 86.2a-2h of the VAT Act and in the provisions of the Minister of Finance Regulation of 17 December 2015 on the manner of determining the scope of using goods and services acquired for economic activities regarding certain taxable persons (Journal of Laws of 2015, item 2193). According to these provisions, in cases of a purchase of goods and services used solely for VAT taxable activities, a taxable person has a right to deduct all input tax included in the purchase price of the goods and services. However, when the goods and services are used both for economic and non-economic activities of a taxable person, in so far as the allocation of the goods or services to economic activities - in whole - is impossible, the taxable person has a right to deduct input tax merely on the part of the amount proportionally attributed to VAT taxable transactions carried out within the scope of the economic activities. The allocation method (the manner of determining the proportion) is chosen by a taxable person himself, however it must correspond to the specificity of the activities carried out by a taxable person and his acquisitions and thus guarantee that the part of expenditure accrued to the economic activities is reflected objectively. For some public institutions, including local government units, an appropriate method (based on revenue and turnover) complying with the 
the Authors, tax authorities will be allowed to challenge the method chosen by a taxable person only in a situation when the other method, guaranteeing more precise (but not the most precise possible) VAT calculation, will be offered.

To sum up, a taxable person acquiring goods or services for the purposes of the economic activities carried out by him is entitled to exercise the right to deduct in its entirety on condition that expenditure made is in direct and immediate connection with the activities covered by the VAT due. In a situation when expenditures made serves for the economic activities as well as for non-economic activities, a taxable person has the right to deduct input VAT only to the extent that expenditure can be proportionally attributed to the taxable person's economic activities. The scope of the deduction is determined according to the methods and criteria accepted by a certain Member State either by way of their implementation to the relevant national legislation or through applied national tax authority practice.

\section{3. "Initial" adjustments of input VAT deduction}

The provisions of the Directive do not refer to the issue of making adjustment of that deduction either - in the same way that they do not regulate the rules on initial deduction of the acquired goods or services used both for economic activities and activities outside the VAT system -. Therefore, these issues are left to the discretion of the Member States ${ }^{16}$. As it was pointed out earlier, in order for the taxable persons to make necessary deduction, the Member States should determine methods and criteria relevant for that purpose, having regard to the principles the common system of VAT is based on ${ }^{17}$. In the opinion of the Authors, the guidelines also consider the obligation to determine rules regarding adjustment of the deduction in a situation any changes occur. The lack of such rules might result in a situation when a taxable person enjoys unjustified advantages or suffers undue losses.

above-mentioned criteria has been envisaged in the implementing Regulation of the Act. The institutions however are not obliged to use the method if the other one - chosen by them - better reflects, in an objective manner, the part of expenditure accrued to the economic activities.

16 For more information see: B. Rogowska-Rajda, T. Tratkiewicz, Generalne zasady wstepnego odliczania podatku naliczonego VAT przez jednostki samorzadu terytorialnego $w$ świetle przepisów unijnych i implementujacych je polskich regulacji, Finanse Komunalne 2017/7-8, pp. 59-73.

17 CJEU judgements in cases: Securenta (C-437/06, paragraphs 33-38); in Portugal (C-496/11, paragraph 42); in joined cases Larentia (C-108/14 and C-109/14, paragraph 27). 


\subsection{The scope of adjustments made}

The issue of adjustments (if there is no doubt that the goods were acquired for the purposes of the economic activities) was brought up in the judgement to the case of Gmina Ryjewo ${ }^{18}$, where it was generally considered necessary to determine the extent to which the goods that formed part of the assets of a business enterprise were to deduct input VAT. It was to be decided to what extent it was possible or obligatory to make adjustment if the conditions for the deduction were fulfilled. In this situation, it was generally considered that the Directive did not envisage the possibility of increasing the initial deduction as a consequence of using for professional purposes the part of the goods allocated at the moment of the purchase for the purposes remaining outside the VAT system ${ }^{19}$. However, this view was not accepted by all EU Member States ${ }^{20}$. This approach, which is in breach of the principle of neutrality, was generally revised by the judgment in the case of Gmina Ryjewo, in which the inclusion in the company's assets was not considered a decisive factor for exercising the right to adjust input VAT. The judgment stated that where the use of the acquired good for activities outside the VAT system does not preclude its use, at least in part, for economic purposes, for instance in connection with a rental transaction, then it is possible to benefit from an input VAT adjustment when the good will actually be used for transactions subject to VAT after a certain period. The CJEU has stated that if an explicit and unambiguous declaration of the intention to use the good for economic purposes on its acquisition may be sufficient to establish that the good was acquired by a taxable person acting as such, the absence of such a declaration does not exclude the possibility that such an intention may be conveyed implicitly ${ }^{21}$. The interpretation of the CJEU, although beneficial to economic operators, seems to be based on vague criteria that may be questioned by the tax administration. In the opinion of the authors, leaving the interpretation of the discussed regulations on a "case by case" basis does not create legal certainty among economic operators.

CJEU judgement in case Gmina Ryjewo (C-140/17).

19 For more information see: B. Rogowska-Rajda, T. Tratkiewicz, Nieodpłatne świadczenie ustug..., p. 38; the position of the European Commission and the Ministry of Finance of the Republic of Poland and representatives of EU Member States during the VAT Committee - vide: Minutes of 108th meeting of the VAT Committee, point 5.8.

20 It should be noted that some Member States have considered that Article 168a of Directive 2006/112/EC may be applicable in this case, which is applicable if the purchased good has been used for business and private activities. In the Commission's opinion, this view is not supported by the judgment in case Landkreis Potsdam-Mittelmark (C- 400/15, paragraph 34).

21 CJEU judgement in case Gmina Ryjewo (C-140/17, paragraph 47). 


\subsection{Rules for making adjustments}

As long as initial deduction is considered, it seems that the most appropriate solution is to allow each method to be used that guarantees that the part of expenditure allocated to economic activities is reflected objectively. For initial adjustment, however, it is the respective application of the rules on making adjustments, as set up in Articles 184-192 of the Directive, that seems to be the most appropriate.

For purchased goods for activities subject to VAT and activities outside the VAT (e.g. as a public authority), the rule on immediate deduction, elaborated on the basis of the use of capital goods for private purposes, does not apply, and no adjustment mechanism as set out in Article 168a of the Directive will apply to such expenditure. The reason is that the adjustment mechanism envisaged in that Article is closely linked to Article 26 of the Directive. The objective for the introduction of the Article was - regarding immovable property used for the purposes of business and private activities - to replace the taxation of private use with the adjustment mechanism. Consequently, as the application of Article 26 was excluded regarding activities outside the VAT system, there is no possibility to apply, with regard to these activities, the adjustment mechanism provided for in Article 168a of the Directive. Additionally, it must be underlined that the adjustment mechanism laid down in Article 168a of the Directive concerns, in general, only immovable property related expenditure (the option contained in paragraph 2 of the Article is omitted here), including services regarding immovable property. It does not refer to other goods or services, hence the application of that solution - even by analogy - to expenditure connected with goods or services used for non-taxable activities appears to be unjustified.

However, as already indicated in the judgment in case Gmina Ryjewo, the CJEU, referring to Articles 167, 168 and 184 of Directive VAT and the principle of neutrality, allowed for the possibility of correcting input VAT when the good was initially used exclusively for activities outside the VAT system (with the potential possibility of using the good for activities subject to VAT) and then, e.g. after several years, for activities subject to VAT. It should be noted that such a change in the purpose of the good may have involved the fact that its purchase was co-financed with EU funds, where the requirement of project sustainability obliged the beneficiary not to use the good for a certain period (usually 5 years) for economic activity. Without entering into settlements in EU funds, projects in the light of VAT regulations, pre-financing of VAT on the purchase of goods from EU funds (VAT in accordance with the purpose of the goods and the beneficiary's 
declaration is not deductible) may mean that the next correction related to the change of purpose will mean, in the area of VAT, unjustified enrichment ${ }^{22}$. However, a refusal to make the appropriate correction would have to be based on national rules.

To sum up, where a taxable person acquires goods and services which are used both for business purposes and outside the VAT system, the taxable person must indicate the extent to which the acquired goods are used for business purposes (if this extent has been initially established on the basis of the figures for the previous year, it is necessary to make it more realistic after the end of the current year). If this range is subsequently reduced, the taxable person is required to correct the deduction made "upside down", and if it is increased, the deduction may be adjusted "upside down" in accordance with the arguments set out in the judgment in case Gmina Ryjewo, taking into account the rules on unjust enrichment, if such rules are provided for in the national system of the Member State concerned.

\section{Conclusions}

In the Authors' view, the rules on input VAT deduction in case of expenditure incurred by the purchase of goods and services used both for the purposes of economic activities carried out by a taxable person and those outside of the VAT system, despite their apparent marginal character, may claim to be one of the most complicated and unrecognised areas within the system of VAT. It is connected mainly with an unprecedented situation of the absence of the rules set up for that field by the legislature of the European Union. The level of complexity in this area is further aggravated by the diversity of the economic reality. This is all reflected in the lengthy opinions of the Advocates Generals and in the jurisprudence of the Court of Justice of the European Union that has tried to fill this legislative gap by its case law.

Undoubtedly, following the judgments in cases: Gmina Ryjewo and Związek Gmin Zagłębia Miedziowego w Polkowicach ${ }^{23}$, issues relating to the deduction and adjustment of input VAT regarding 'mixed' activities seem to be clearer. However, in the absence of appropriate regulations in the VAT Directive, doubts

22 For more information see: CJEU judgement in case Alakor Gabonatermelő és Forgalmazó Kft (C-191/12).

23 CJEU judgements in cases: Gmina Ryjewo (C-140/17), Związek Gmin Zagłębia Miedziowego w Polkowicach (C-566/17). 
remain as to the uniformity of approach in this area by the Member States, which may result in an unequal competitive situation for entities depending on their establishment. In addition, the matter is complicated by the determination of the scope of adjustments to input VAT associated with mixed use, if only in the context of different approaches in Member States to the issue of unjustified enrichment. In the authors' opinion, there is, therefore, a need to clarify at the European Union level the issues related to the deduction and adjustment of input VAT on purchases of goods and services used both for the purposes of the taxpayer's business activity and for purposes outside the VAT system. The adoption of the rules, as was the case for the acquisition of goods for business and private purposes, would undoubtedly not only reduce legal uncertainty in this area, but would also harmonise the treatment of taxable persons in the various Member States.

\section{References}

\section{Legal acts}

Council Directive 2006/112/EC of 28 November 2006 on the common system of value added tax, Official Journal of the European Union, L 347/1 (2006).

Minister of Finance Regulation of 17 December 2015 on the manner of determining the scope of using goods and services acquired for economic activities regarding certain taxable persons (Journal of Laws of 2015, item 2193).

Sixth Council Directive of 17 May 1977 on the harmonization of the laws of the Member States relating to turnover taxes - Common system of value added tax: uniform basis of assessment (77/388/EEC), Official Journal of the European Communities, No L 145/1 (1977).

\section{Literature}

Maliński M., Prewspółczynnik VAT - kontrowersje wokót proporcjonalnego odliczenia VAT naliczonego w stanie prawnym przed 1.01.2016 r., Przegląd Podatkowy 2016/11, s. 31-40.

Opinion of Advocate General of 20 January 2005 in case C-434/03, Charles and T.S. Charles-Tijmens, EU:C:2005:48.

Opinion of Advocate General of 22 December 2008 in case C-515/07, VNLTO, EU:C:2008:769.

Opinion of Advocate General of 10 April 2014 in case C-92/13, Gemeente's Hertogenbosch, EU:C:2014:267.

Opinion of Advocate General of 26 March 2015 in joined cases C-108/14 and C-109/14, Larentia, EU:C:2015:212.

Opinion of Advocate General of 25 November 2015 in case C-332/14, Wolfgang, EU:C:2015:777. Opinion of Advocate General of 6 April 2017 in case C-132/16, Iberdrola, EU:C:2017:283.

Rogowska-Rajda B., Tratkiewicz T., Generalne zasady wstepnego odliczania podatku naliczonego VAT przez jednostki samorządu terytorialnego w świetle przepisów unijnych i implementujacych je polskich regulacji, Finanse Komunalne 2017/7-8, s. 59-73. 
Rogowska-Rajda B., Tratkiewicz T., Nieodpłatne świadczenie ustug w podatku VAT w orzecznictwie Trybunału Sprawiedliwości, Europejski Przegląd Sądowy 2015/11, s. 35-43.

Rogowska-Rajda B., Tratkiewicz T., Odliczanie podatku naliczonego VAT od wydatków zwiazanych z samochodami w świetle prawa unijnego, Europejski Przegląd Sądowy 2017/4, s. $15-24$

\section{Judgements}

CJEU judgement of 27 September 2001 in case C-16/00, Cibo, EU:C:2001:495.

CJEU judgement of 21 April 2005 in case C-25/03, HE, EU:C:2005:241.

CJEU judgement of 26 Mai 2005 in case C-465/03, Kretztechnik, EU:C:2005:320.

CJEU judgement of 14 July 2005 in case C-434/03, Charles and T.S. Charles-Tijmens, EU:C:2005:463.

CJEU judgement of 30 March 2006 in case C-184/04, Uudenkaupungin kaupunki, EU:C:2006:214.

CJEU judgement of 14 September 2006 in case C-72/05 Wollny, EU:C:2006:573.

CJEU judgement of 8 February 2007 in case C-435/05, Investrand, EU:C:2007:87.

CJEU judgement of 13 March 2008 in case C-437/06, Securenta, EU:C:2008:166.

CJEU judgement of 12 February 2009 in case C-515/07, VNLTO, EU:C:2009:88.

CJEU judgement of 23 April 2009 in case C-460/07, Puffer, EU:C:2009:254.

CJEU judgement of 16 February 2012 in case C-594/10, T.G. van Laarhoven, EU:C:2012:92.

CJEU judgement of 16 February 2012 in case C-118/11, Eon Aset Menidjmunt, EU:C:2012:97.

CJEU judgement of 6 September 2012 in case C-496/11, Portugal, EU:C:2012:557.

CJEU judgement of 8 November 2012 in case C-511/10, BLC Baumarkt, EU:C:2012:689.

CJEU judgement of 16 Mai 2013 in case C-191/12, Alakor Gabonatermelö és Forgalmazó Kft, EU:C:2013:315.

CJEU judgement of 10 July 2014 in case C-183/13, Banco Mais, EU:C:2014:2056.

CJEU judgement of 10 September 2014 in case C-92/13, Gemeente's Hertogenbosch, EU:C:2014:2188.

CJEU judgement of 16 July 2015 in joined cases C-108/14 and C-109/14, Larentia, EU:C:2015:496

CJEU judgement of 9 June 2016 in case C-332/14, Wolfgang, EU:C:2016:417.

CJEU judgment of 15 September 2016 in case C- 400/15, Landkreis Potsdam-Mittelmark, EU:C:2016:687.

CJEU judgement of 25 July 2018 in case C-140/17, Gmina Ryjewo, EU:C:2018:595.

CJEU judgement of 8 Mai 2019 in case C-566/17, Związek Gmin Zagłębia Miedziowego w Polkowicach, EU:C:2019:390.

\section{Websites}

Minutes of 108th meeting of the VAT Committee, https://circabc.europa.eu/ui/group/cb1eaff7eedd-413d-ab88-94f761f9773b/library/ac8d5b66-6907-4a0f-9f2b-69836334bc4d/details; accessed 31.10.2020. 
Beata ROGOWSKA-RAJDA, Tomasz TRATKIEWICZ

\title{
ODLICZANIE I KORYGOWANIE PODATKU NALICZONEGO W VAT PRZY GOSPODARCZYM I POZAGOSPODARCZYM WYKORZYSTYWANIU TOWARÓW I USŁUG
}

\begin{abstract}
Abstrakt
Przedmiot badań: Przedmiotem badań była analiza przepisów i orzecznictwa unijnego w zakresie odliczania i korygowania w systemie VAT podatku naliczonego przy gospodarczym i pozagospodarczym wykorzystywaniu towarów i usług. Zagadnienie to budziło w ostatnich latach wiele kontrowersji i było przedmiotem kilku rozstrzygnięć Trybunału Sprawiedliwości, obrad Komitetu ds. VAT, a także przedmiotem rozstrzygnięć krajowych sądów administracyjnych i interpretacyjnych Ministra Finansów/Dyrektora Krajowej Informacji Skarbowej. W opracowaniu podjęto się analizy przedmiotowej, zwracając jednocześnie uwagę na istniejące nadal mimo ostatnio wydanych wyroków TSUE wątpliwości w jednolitym stosowaniu przepisów.

Cel badawczy: Celem badań była nie tylko ocena samych regulacji prawnych czy interpretacji tych przepisów, ale przede wszystkim zwrócenie uwagi na kwestie związane z brakiem regulacji na szczeblu unijnym w badanym obszarze, który prowadził i nadal może prowadzić wśród państw członkowskich UE do niejednolitego stosowania przepisów w zakresie VAT.

Metoda badawcza: Przy pracy nad artykułem, co uzasadnia charakter badań historyczno-prawnych, wykorzystano przede wszystkim metodę badawczą dogmatyczną oraz historyczną.

Wyniki: Zidentyfikowano istotne zróżnicowanie wśród państw członkowskich w zakresie odliczania i korekt przy wykorzystaniu mieszanym towarów i usług. Mimo ostatnio wydanych wyroków TSUE nadal istnieje stosunkowo duży margines do interpretacji, który może powodować zróżnicowanie pozycji prawno-podatkowej podmiotów w poszczególnych państwach członkowskich UE. Istnieje zatem potrzeba doprecyzowania regulacji w omawianym zakresie w ustawodawstwie unijnym.
\end{abstract}

Słowa kluczowe: VAT, odliczanie podatku naliczonego, gospodarcze i pozagospodarcze wykorzystywanie towarów i usług, korekta odliczenia podatku naliczonego, zasada neutralności. 